birthday on November 23, 1939, and the first award was made on that date to Dr. Poulsen himself. Owing to the War, it was not possible to make further awards until 1946, when medals were awarded to Dr. E.F.W. Alexanderson and to SirRobert Watson-Watt. Dr. E. F. W. Alexanderson was awarded a Valdemar Poulsen Gold Medal for outstanding contributions to radio-technics, and particularly for the development of a radio-frequency alternator of high power and other system components important in the early progress of radio communication; Dr. Alexanderson was born in Sweden, but his whole work with radiotechnics has been done in the United States, where he is a chief engineer of the General Electric Co. at Schenectady.

Sir Robert Watson-Watt was awarded a Valdemar Poulsen Gold Medal for outstanding contributions to the development of radio and particularly for his leading scientific part in the invention and development of the use of radiolocation.

\section{New Chairmen of Research Boards}

THe Lord President of the Council has made the following appointments to chairmanships of research boards of the Department of Scientific and Industrial Research from April 1, 1947 : Sir Edward Salisbury, director of the Royal Botanic Gardens, Kew, to be chairman of the Forest Products Research Board in succession to Prof. V. H. Blackman ; Engineer ViceAdmiral Sir Harold Brown, recently senior supply officer, Ministry of Supply, formerly engineer-in-chief of the Fleet and, during the War, controller general of munitions production, to be chairman of the Fuel Research Board in succession to Sir Harold Hartley; Sir Stanley Angwin, chairman of Cable and Wireless, Ltd., formerly engineer-in-chief of the General Post Office, to be chairman of the Radio Research Board in succession to Lieut -Colonel Sir George Lee.

\section{A New Form of Camera}

Mr. EDwIN H. LAND, president and director of research of the Polaroid Corporation, demonstrated recently before the Optical Society of America a camera which produces a dry positive on paper 60 sec. after releasing the camera shutter. The camera contains a roll of film of conventional type, except that the support is opaque, and the exposure is made in the usual way. The camera also contains a roll of specially prepared paper which is not sensitive to light. The paper support is also opaque, and has attached, at intervals equal to the length of the picture, capsules containing a viscous solution of the processing materials. This solution includes hydroquinone and 'hypo' and is released when the capsule is burst on passage of the film and paper between pressure rollers. This takes place after exposure, and the solution is spread as a thin layer between the film and paper, where the following action is said to take place. The hydroquinone rapidly reduces the silver halide in the film in those regions where light action has taken place, thus immobilizing the silver in these regions. In the unexposed regions the 'hypo' takes the silver halide into solution, and diffusion and reduction take place, with the result that silver is deposited in the prepared surface of the paper, producing an image in silver. Since most silver is deposited in the paper in those regions where the least exposure occurs in the camera, the paper image is a positive. The film and paper are pulled apart when the action is complete, yielding a paper 'print' which has a slightly damp surface. The film-paper sandwich passes out of the camera immediately after passing the pressure rollers. The purpose of the opaque supports is to protect the film trom further light action while the 'processing' is taking place. In some variants of the system further prints can be obtained from the 'negative', but in general it appears necessary to rephotograph the original to obtain further copies.

\section{Historia Naturalis}

IN September 1944, a small group of biologists met in Rome to consider means of promoting the interests of their science, and by December of the same year their suggestions had received sufficient support to justify the formation of a society of naturalists, Unione Italiana Naturalisti. By 1946, the society was strong enough to issue its own journal. This publication, Historia Naturalis, is about the same size as Nature, and each part so far published consists of 24 pages, exclusive of the cover. It is illustrated with line and half-tone text figures and is quite well printed. It appears three times a year-in March, June and September-and the issues of the first year are now to hand.

The object of the journal is not merely to record the meetings and activities of the society, which are many-indeed these only occupy a page or two-but to emphasize the fundamental unity of the biological sciences, interpreting these in a wide sense. It appeals not only to the professional specialist but also to the intelligent amateur. The major portion of each issue is therefore devoted to original studies and researches, to reports of conferences and symposia, to reviews and essay reviews covering diverse aspects of natural history. The original contributions have included, among others, general and vertebrate palæontology, geology (tectonics), evolutionary prob. lems, animal populations and experiments on Coleop. tera. We should like to congratulate our colleagues on their courage in making a start in this field when general conditions were far from encouraging, and welcome the new journal, which undoubtedly fills a need. If the publication fulfils the prcmise of its first year-and there is no apparent reason why it should not-it is assured of a permanent place in scientific literature. The annual subscription to Historia Naturalis is 150 lire, to be sent to Domenico Rossi, via Tomacelli, 132, Rome.

\section{Engineering Degree Courses for Ex-Servicemen}

MANY who were studying engineering before being called up for national service have been unable to complete degree courses, and although they have become competent engineers, their future career would benefit greatly if they were able to obtain a degree. Mr. O. S. Puckle, of R.F. Equipment Ltd., Langley Park, near Slough, Bucks, believes that suitable courses of study at a number of technical colleges throughout Great Britain, either in the form of a full day on Saturday or a half-day on Saturday and, say, one, or at most two, evenings per week, could be devised to meet this need. He therefore invites engineers or physicists who are interested in such a proposal to communicate with him. Should the number of replies prove to be sufficient, he proposes to communicate with the Ministry of Education in order to ascertain whether something can be done to meet the situation. He has in mind two types of course, covering two or three years and leading to final B.Sc. or B.Sc.(Eng.), depending on whether the intermediate examination has been 
passed. Replies, stating the nearest technical college which could be attended, should be sent to $\mathrm{Mr}$. Puckle as early as possible.

\section{World Power Conference on Fuel Economy}

A PReliminary programme has been issued of a sectional meeting of the World Power Conference to be held at 'The Hague during September 2-9, 1947, when the subject of discussion will be "Fuel Economy". The proceedings will be divided into three sections dealing with production, distribution and utilization respectively. Copies of national reports on fuel economy prepared at the request of the central office of the World Power Conference and also of all printed papers prepared for the meeting will be supplied to members of the Conference ; all sessions will be devoted to oral discussion. Papers can only be submitted through national committees ; the address of the British National Committee is 201-2 Grand Buildings, Trafalgar Square, London, W.C.2, to which intending members resident in Great Britain should apply for particulars. The address of the secretariat for the meeting is Vereeniging voor Congressen op Electrotechnisch en Aanverwant Gebied, 210 Utrechtscheweg, Arnhem, Netherlands.

\section{X-Ray Analysis Conference}

The 1947 Conference of the X-Ray Analysis Group of the Institute of Physics will be held at the Royal Institution, Albemarle Street, London, during April 22-23. The first day will be devoted to discussion of the training of $\mathrm{X}$-ray crystallographers for science and for industry; the second will be devoted to new techniques and results. Mr. H. P. Rooksby, of the Research Laboratories, General Electric Co. Ltd., Wembley, will give an evening lecture on the technique of X-ray powder photography on April 22. Short papers only are being given, so as to leave time for informal discussions. The Conference is open to all interested in the subject. Further particulars can be obtained from the honorary secretary of the Group, Dr. F. A. Bannister, British Museum (Natural History), London, S.W.7.

\section{Conference on Applications of Radioactive Tracer Elements}

A CONFERENCE is being arranged by the Manchester and District Branch of the Institute of Physics on "Applications of Radioactive Tracer Elements in Physics Research and Industry" during July 10-12 in the Physics Department of the University of Manchester. The opening papers will be given by Dr. J. D. Cockeroft, Prof. F. Paneth and Mr. D. H. Wilkinson. The conference will be open to anyone interested, without charge, but admission will be by ticket only. Further particulars will be issued in due course by the Conference Secretary, W. J. Meredith, Christie Hospital and Holt Radium Institute, Wilmslow Road, Manchester 20.

\section{University of Durham : Appointments}

THE following appointments have been made in the University of Durham: Martin Jones, to be professor of agricultural botany at King's College, Newcastle; Ewen M'Ewen, to be professor of engineering in the Faculty of Agriculture at King's College, Newcastle; Alexander Kennedy, to be professor of psychological medicine at King's College, Newcastle; Leonard Slater, to be reader in geography in the Durham Colleges.

\section{Arthur Stanley Eddington Memorial Lectureship}

LAST year an appeal was launched to provide for the founding of an Arthur Stanley Eddington Memorial Lectureship to commemorate Eddington's life and work, by providing for lectures on some aspect of contemporary scientific thought considered in its bearing on the philosophy of religion, or on ethics, and to be delivered periodically in Cambridge, or elsewhere, and to be published. The Foundation Trust Deed has now been completed, and the following four trustees have been appointed: Prof. Sydney Chapman, representing the Royal Society; Prof. C. D. Broad, representing Trinity College, Cambridge; Dr. Kathleen Lonsdale and Dr. W. H. Thorpe, representing the Society of Friends. Mr. Howard Diamond, 45 St. Barnabas Road, Cambridge, is honorary treasurer and secretary of the trustees. The Fund is still open, and approximately $£ 1,000$ is now needed for its completion. It is hoped that the first lecture on the Foundation will take place towards the end of the present year.

\section{The Boron-Trifluoride Catalysed Reaction of Di- isobutene}

Dr. Alwyn G. Evans and M. A. Weinberger write : "In our recent communication on this subject [Nature, March 29, p. 437], it is stated that the addition of acetone vapour, purified by distillation in vacuo over freshly distilled sodium, to a non-reacting mixture of di-isobutene vapour and boron trifluoride initiates the fast reaction of di-isobutene. In our corrected proof of this letter [received too late for changes to be made. Editors] we deleted this statement on the grounds that since traces of water are so effective in initiating this reaction, we do not as yet wish to claim that completely pure acetone itself is effective in this way."

\section{Announcements}

THe James Watt International Medal for 1947 of the Institution of Mechanical Engineers will be presented to Prof. S. Timoshenko, recently professor of engineering at Stanford University, California, on April 25; he will speak on "Stress Concentration and Fatigue Failures".

Mr. F. Brundrett, of the Royal Naval Scientific Service, has been appointed chief of the Service in succession to Sir Charles Wright, who retires on April 30.

By arrangement between the University of Sheffield and the Council of the Iron and Steel Institute, the second Hatfield Memorial Lecture will be given by Dr. C. Sykes, of the Brown-Firth Research Laboratories, Sheffield, in the Institution of Civil Engineers, London, on May 14 at 8.30 p.m., on the occasion of the annual general meeting of the Iron and Steel Institute, and will be entitled "Steels for Use at Elevated Temperatures".

Dr. Douglas Guthrie is delivering a course of lectures in the University of Edinburgh on the history of medicine, beginning on April 17. As part of the course, guest lectures will be given by Sir Arthur MacNalty on the evolution of preventive medicine in Britain on May 16, and by Sir Henry Bashford on Hans Sloane on May 23.

Erratum. In the communication "Spiral Cracks in Glass Tubes" by Dr. L. Norzi, published in Nature of March 1, p. 306, paragraph 5, line 2, for "tg $2 \varphi=2 C|(B-A)|$ " read "tg $2 \varphi=2 C /|(B-A)| "$. 